B 310

NO-LIF 及びPSP を用いた側壁付きリニアエアロスパイクノズルの評価

\author{
○正 谷口真潮 $($ 名大・院) 正 森英男 (名大) 西平竜太郎 (名大・院) \\ 福島敦至 (名大・院) 正 新美智秀 (名大)
}

\title{
Investigation of Linear-Type Aerospike Nozzle with Sidewalls using NO-LIF and PSP
}

\author{
Mashio TANIGUCHI, Hideo MORI, Ryutaro NISHIHIRA, \\ Atsushi FUKUSHIMA and Tomohide NIIMI
}

\begin{abstract}
An aerospike nozzle has been expected as a candidate for an engine of reusable space shuttle to respond to growing demand for rocket-launching and its cost reduction. It has been reported that sidewalls of linear-type aerospike nozzles can suppress undesirable sideward flow expansion. In this study, the flow field around the linear-type aerospike nozzle with sidewalls and the nozzle without sidewalls are compared to confirm the effect of the sidewalls experimentally. Laser induced fluorescence is used to visualize and analyze flow fields around the nozzles. PSP is also applied to measurement of pressure distribution on the nozzle surfaces. The nozzles are set into a vacuum chamber to achieve larger pressure ratios $P R\left(P_{s}\right.$ : source pressure in a reservoir, $P_{a}$ : ambient pressure in a vacuum chamber) because jet structures are affected mainly by pressure ratios.
\end{abstract}

Keywords: Aerospike Nozzle, Jet Structure, LIF, PSP, Sidewalls

\section{1 緒言}

ロケット打ち上げ需要の拡大に伴ら低コスト宇宙輸送シス テムの要求が高まるにつれて単段式完全再使用宇宙往還機の 実用化が期待され，推進装置としてエアロスパイクノズル11 が有望視されている. 我々はこれまでリニアエアロスパイク ノズルの流れ場解析を行い，噴流の複雑な 3 次元構造を明ら かにしてきた2).しかしながら，リニアエアロスパイクノズ ルの形状は 2 次元流を仮定して設計されるため，側方への 膨張は推力の損失を引き起こす，そこで，側方への膨張を抑 制するためにノズル両端に側壁を設置する手法が提案され， Ito $5^{3)}$ による数值解析が行われている. 本研究では, 任意 断面での可視化が可能な NO-LIF を用いた流れ場解析及び PSP を用いたノズル表面の圧力分布計測を行い,リニアエ アロスパイクノズルの側壁の効果を実験的に解析する.さら に, 幅広い压力比 $\left(P R=P_{s} / P_{\alpha}, P_{s}\right.$ 貯気室圧力, $P_{a}$ :膨 張空圧力）を可能にするため，ノズルを真空チャンバー内に 設置し，低圧環境下で実験を行う.

\section{2 実験装置}

Fig.1 に本研究で用いた NO-LIF による可視化計測システ 厶機器構成を示す．実験装置は，真空チャンバー，給排気装 墨, 圧力測定装置, 光学系および同期システムからなる. 本 研究では, $\mathrm{NO} 2 \%+\mathrm{N}_{2} 98 \%$ の混合気体をノズルから噴出し, ArF エキシマレーザー (Lambda Physik: LPX 105E) から 発したレーザー光を複数のミラーを用いて伝搬した後に円筒 レンズ (シグマ光機 : $\mathrm{f}=400 \mathrm{~mm}, 20 \times 30 \mathrm{~mm}$ ) によりシート 状にし，エアロスパイクノズル周りの流れ場に入射した。本 研究で使用した $\mathrm{ArF}$ エキシマレーザーは波長 $193 \mathrm{~nm}$, 半值 幅 $0.5 \mathrm{~nm}$, レーザー光強度 $120 \mathrm{~mJ} /$ pulse である. 流れ場中の 微弱な紫外蛍光を撮像するために，イメージインテンシファ イヤー (浜松ホトニクス: C6653) を取り付けた CCD カメラ
(浜松ホトニクス: C7300-10) をレーザーシートに対して垂 值に設置した。なお，CCD カメラの解像度は $1280 \times 1024$ 画 素, 4096 階調 (12bit) である. また，カメラレンズ (Nikon: UV-NIKKOR F(0.5)) にUG5 フィルターを取り付けるとと もに，レーザーの発振と CCD カメラの撮像時間を同期させ ることにより，散乱光を大幅に軽減した．CCD カメラで撮 像されたデータは，専用のインターフェイスコニットに送ら れ，データ処理を行った後にホストコンピューターに格納さ れ，モニターに出力される．また，カメラレンズの被写界深 度が浅いので，焦点が常に合うようにパルスステージを用い てレーザーシートとCCD カメラが等距離を保つように CCD カメラを移動させた.

PSP を用いたノズル表面の圧力分布計測にも同様の実験 装置を用いたが，試料気体として純酸素を，入射光源として キセノンショートアークランプ (ウシオ電機 : UXL-500SX) を用いた. ランプからの光を透過波長域 $400 \pm 10 \mathrm{~nm}$ のバン ドパスフィルターを用いて PtTFPP の吸収波長域の光を取 り出し，リキッドファイバーを介してチャンバー内に設置し たPSP を塗布したノズル表面に照射した. $600 \mathrm{~nm}$ のロング パスフィルターを CCD カメラの前に設圆し, PSP の発光の みを撮像した. PSP には本研究で使用する圧力領域に最も 適した PtTFPP/poly-IBM-co-TFEM ${ }^{5) 6)}$ を用いた。奉験条 件として貯気室压力を $9.0 \times 10^{4} \mathrm{~Pa}$ に固定し，背圧である膨 張室圧力を制御することで圧力比を 30 から 200 まで変化さ せた。

本研究ではFig.2(a) 及び (b) に示すりニアエアロスパイ クノズルを使用して実験を行った. なお，Fig.2(a) 及び (b) には本研究で使用した座標系を併せて示す．噴射口断面を $y z$-平面とし，この面に垂直かつノズルのベース面の中心を 通る直線を $x$ 軸とする. 本研究で使用するリニアエアロスパ 


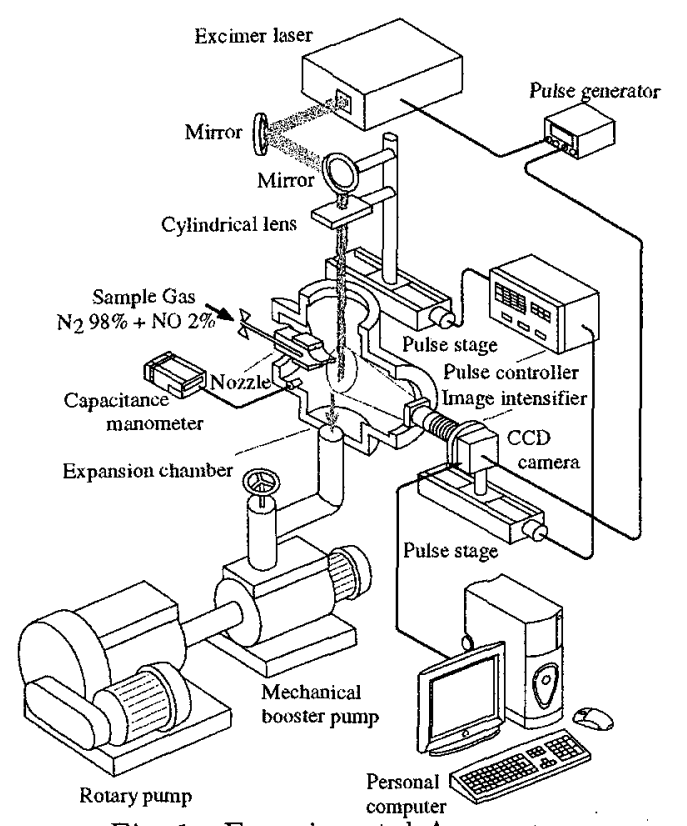

Fig. 1 Experimental Apparatus

イクノズルは膨張過程を等エントロピー上仮定し，貯気室か ら噴射口までの内部膨張部と噴射口からスパイク部先端まで の外部膨張部に分け, 特性曲線法により設計を行った7)。 ズル断面は矩形とし， $P R=100$ のとき道正膨張となるよう にスパイク部先端ノズル断面積とスロート断面積の面積比 を8.117 とした. Fig.2(a)に示すように，スパイク面に沿っ た流れ場及びスパイク面上の圧力分布を解析するために，設 計で得られたスパイクを全長の $60 \%(8.66 \mathrm{~mm})$ で切断して スパイクを隔てた片側に噴射口を設置したノズルを作製した (Nozzle A).Fig.2(b) に示すように，スパイクを隔てた両 側から膨張する埴流の干渉を含む流れ場を解析するために， 設計で得られたスパイクを全長の $20 \%(2.89 \mathrm{~mm})$ で切断し てスパイクを隔てた両側に噴射口を設置したノズルを作製し た（Nozzle B）.Fig.2(c) は本研究で使用したノズルの断面 図である. 噴射口断面（Cowl Lip を含む平面）とノズル中 心軸の交点を原点とし，原点より左側が内部膨張部，右側が 外部膨張部である。.また，ノズルスロートの高さを $0.5 \mathrm{~mm}$ とした，側壁は，NO-LIFによって発した営光を撮像するた めに紫外光を透過する石英ガラスを用いた．なお，原点から Cowl Lip までの距離を $z_{e}$ とし, 全ての距離及び長さを $z_{e}$ で無次元化した.

\section{3 結果および考察}

\section{1 スパイク表面を沿う流れ場解析}

スパイク表面に沿って流れる噴流を解析するためにスパイ ク長 $60 \%$ フズル（Nozzle A）を用い, NO-LIFにより噴流 構造を可視化するとともに，PSPによりスパイク表面の圧 力分布を計測した.

2次元等エントロピー流れを仮定して設計されるリニアエ アロスパイクノズルに対し，側方への膨張を抑制することで 推力低下を防ぐことを目的とした側壁をノズルに設置して側 壁の有無によるスパイク表面の流れ場の差異を比較すること により，側壁の有効性を調查した

設計圧力比（本研究のノズルは $P R=100 ）$ において， 2 次元, 等エントロピー仮定におけるエアロスパイクノズルの 噴流の流線は Cowl Lip を中心としたプラントル・マイヤー 膨張扇によって常にスパイク表面に平行になるように偏向す るので，ノズル出口の流線はノズル中心軸 ( $x$ 軸) に対して

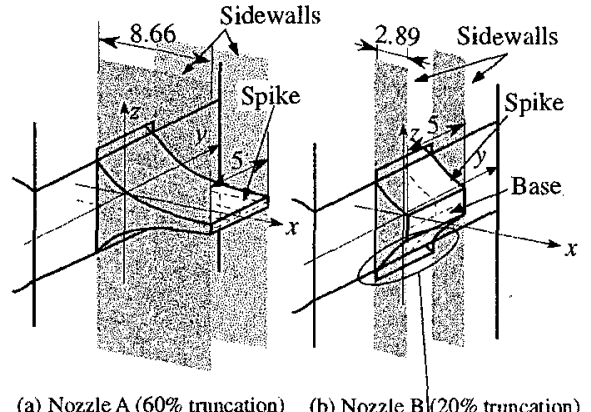

(a) Nozzle A (60\% truncation) (b) Nozzle B $(20 \%$ truncation)

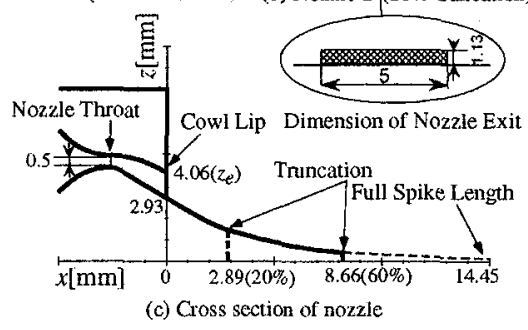

Fig. 2 Aerospike Nozzles

平行となり，噴流境界もノズル中心軸に対して平行となる8)

Fig.3(a) 及び (b) はそれぞれ $P R=100$ における側壁 付きノズル及び側壁のないノズルに関する NO-LIF による $x z$-平面の可視化画像を示し, Fig.4 及びFig.5 はそれぞれ $P R=100$ における側壁付きノズル及び側壁のないノズルに 関する NO-LIF による $y z$-平面の可視化画像を示し, 撮像位 置は (a) $x / z_{e}=0.412$ 及び (b) $x / z_{e}=2.134$ である.

Fig.3(a) に示すように，設計圧力比 $P R=100$ において， 側壁付きノズル周りの噴流はノズル中心軸に対して平行であ ることが確認でき, Fig.3(b) から, 側壁のないノズルの噴流 境界は下流に向かうに従って収束していく様子が確認できる. また，Fig.4 及び Fig.5 に示す $y z$-平面に平行な可視化画像 から，噴流の側方への膨張は側壁によって㧕制されているこ とが確認できる，以上の結果から，設計圧力比 $(P R=100)$ において，リニアエアロスパイクノズルの噴流は側壁の設置 により，側方への膨張が抑制されて噴流境界はノズル中心軸 に対して平行になるので，㑡壁付きリニアエアロスパイクノ ズルの噴流は適正致張していると考えられる。

次に，側壁の有無によるスパイク表面の圧力分布の差異を PSP を用いて検証した. Fig.6(a) 及び (b) はそれぞれ PSP により計測した $P R=100$ における側壁付きノズルのスパ イク表面の圧力分布及び側壁のないノズルのスパイク表面の 圧力分布である.Fig.6(a) 及び (b) に示すように，側壁付き ノズルのスパイク表面の圧力分有は $y$ 方向にほぼ一様である のに対して，側壁のないノズルのスパイク表面の圧力分布は ノズル中心軸 $(x$ 軸) 上が最も高く，側方に向かうにつれて 圧力が減少していく様子が確認できる．Fig.6(b) 上の破線は スパイク表面の圧力が背圧と等しい位置を示し，破線より下 流ではスパイク表面の圧力は背圧よりも低い.これは Fig.5 に示すように，側壁のないノズルの噴流が噴射口直後から側 方へと膨張するために起こる，一方，側壁の付きノズルのス パイク表面の圧力は全体にわたって背圧よりも高くなったの で側壁の設置によりスパイク表面の圧力は $y$ 方向にほぼ一様 となり，背圧よりも低くなることはないことを明らかにした。

設計圧力比 $(P R=100)$ に方いて側壁のないノズルの噴 流とは異なり，側壁付きノズルの噴流は適正膨張してスパイ ク表面の圧力は側壁のないノズルの圧力よりも高くなるので 側壁の設置により推力の增加が見込まれる. 


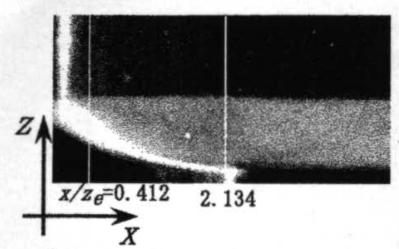

(a) Nozzle with Sidewalls

Fig. 3 LIF Image on $x z$-plane of Nozzles, $P R=100$

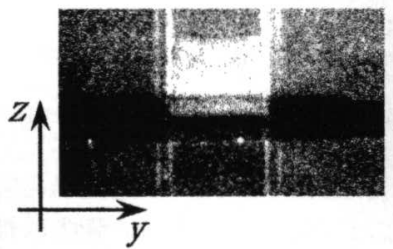

(a) $x / z_{e}=0.412$

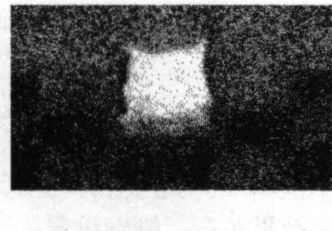

(b) $x / z_{e}=2.134$

Fig. 4 LIF Image on $y z$-plane of Nozzle with Sidewalls, $P R=100$

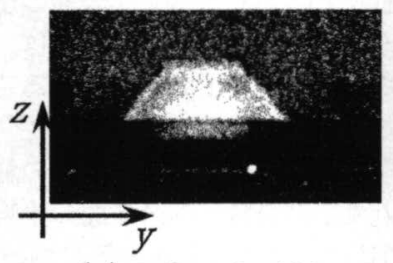

(a) $x / z_{e}=0.412$

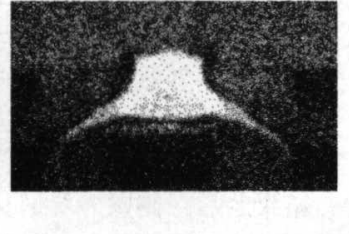

(b) $x / z_{e}=2.134$
Fig. 5 LIF Image on $y z$-plane of Nozzle without Sidewalls, $P R=100$

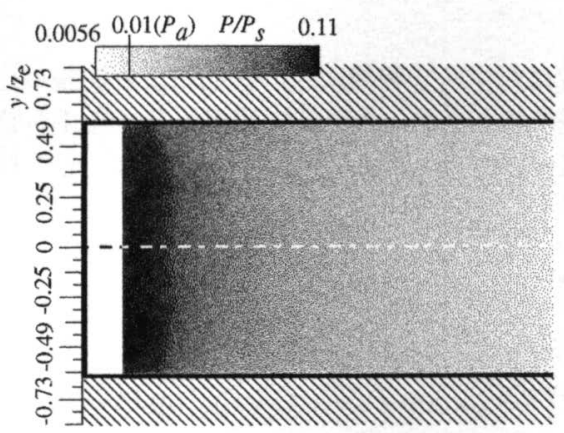

(a) Nozzle with Sidewalls

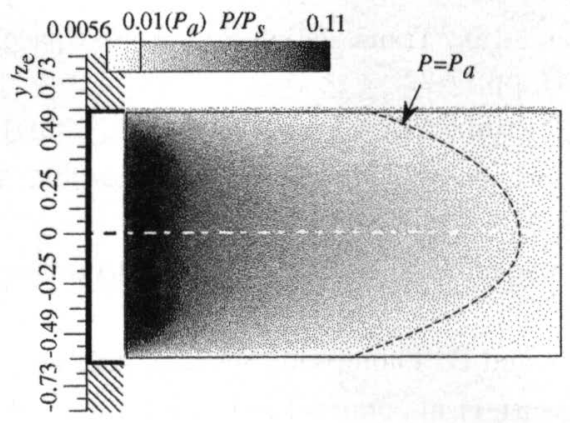

(b) Nozzle wi thout Sidewalls

Fig. 6 Pressure Distribution on Spike, $P R=100$
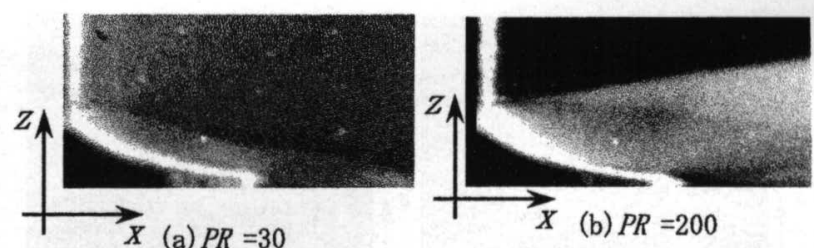

Fig. 7 LIF Image on $x z$-plane of Nozzle with Sidewalls

異なる圧力比における側壁付きノズル周りの流れ場を解 析するために, 設計圧力比未満 $(P R=30)$, 設計圧力比 $(P R=100)$, 設計圧力比より大きい圧力比 $(P R=200)$ における流れ場を比較した. Fig.7(a) 及び (b) はそれぞれ $P R=30,200$ における $x z$-平面の可視化画像を示す $(P R=$ 100 は Fig.3(a) 参照). Fig.7(a),(b) 及び Fig.3(a) からエア ロスパイクノズルの特徴である外気圧に応じて噴流形状が変 化する様子が確認できるが, 低圧力比 $(P R=30)$ を含む全 ての圧力比において噴流はノズル壁面から剥離していないこ とがわかる. ゆえに，リニアエアロスパイクノズルの噴流で はベル型ノズルで問題となる低圧力比における過膨張噴流の ノズル壁面からの剥離が生じないことを明らかにした。

圧力比によるスパイク表面の圧力分布の差異を確認する ため, PSP を適用して $P R=30,50,100,170$ 及び 200 におけ るスパイク表面の圧力分布を測定した. どの圧力比において も，側壁の設置により圧力分布は $y$ 方向に対してほぼ一様で あることを実験的に確認できた，そこで, 各圧力比における スパイク表面の圧力の変化を詳細に示すため, PSP により 計測したスパイク表面の中心軸上 $\left(y / z_{e}=0\right)$ における圧力 を Fig.8 に示す. 縦軸に示すスパイク表面の圧力を貯気室圧 力 $\left(P_{s}=9.0 \times 10^{4} \mathrm{~Pa}\right)$ で無次元化した. Fig.8 に示すよう に, 設計圧力比以上 $(100 \leq P R)$ ではスパイク表面の圧力 は外気圧に依存せずにほぼ一様になることがわかる，一方， 設計圧力比未満 $(P R<100)$ において，上流のスパイク表 面の圧力は設計圧力比以上の場合と同様に減少していくが, 下流で圧力上昇が生じることが確認できる. 圧力上昇が起こ るときの圧力は, $P R=30$ において $P / P_{s}=0.033$ であり, $P R=50$ において $P / P_{s}=0.02$ である. これらの圧力值 $\left(P / P_{s}\right)$ は, それぞれ外気圧と等しい. つまり, 設計圧力比 未満では, スパイク表面の圧力が外気圧と等しくなったとき 圧力上昇が生じる. 以上の結果から，側壁付きリニアエアロ スパイクノズルのスパイク表面の圧力は, 設計圧力比以上で は外気圧に依存せず, 一様な傾向を示すが, 設計圧力比未満 では，噴射ロよりスパイク面に沿って膨張する噴流は噴流圧 力が外気圧と等しくなる場所で, 圧力上昇が起こることを実 験的に明らかにした.

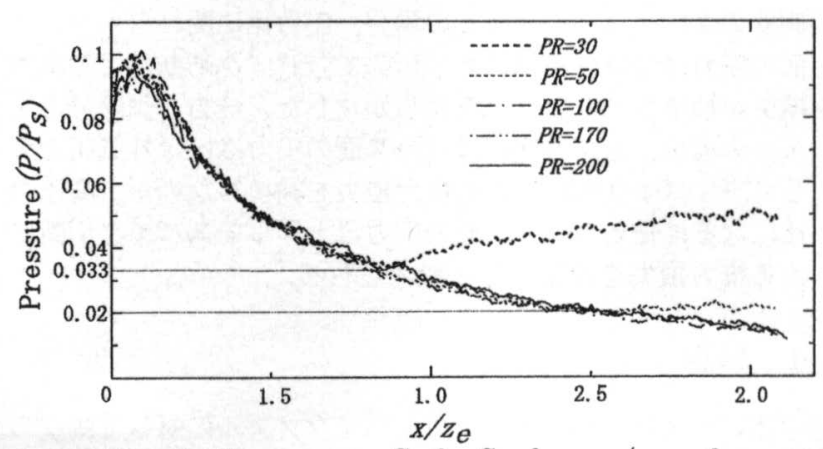

Fig. 8 Pressure on Spike Surface, $x / z_{e}=0$ 


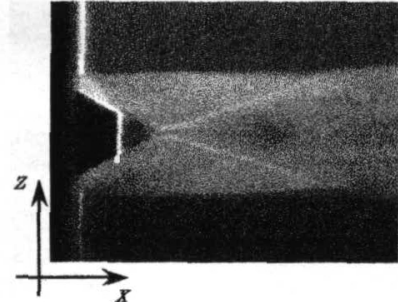

(a) Nozzle with Sidewalls

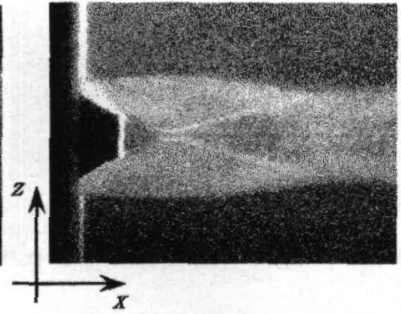

(b) Nozzle without Sidewalls ne of Nozzles, $P R=100$

\section{2 スパイク部の両側より噴出する噴流の干渉を含 んだ流れ場解析}

通常, エアロスパイクノズルはベル型ノズルよりも全長 が長くなるが，切断面（ベース面）にかかる圧力によって スパイク切断に伴う損失が補填されることが報告されてい る ${ }^{3)}$. スパイク切断による推力損失の補填が起こる結果を実 験的に検証するため, スパイク長 $20 \%$ （Nozzle B）を用いて NO-LIF による可視化解析及び PSP によるべース面の圧力 分布計測を行った. Fig.9(a) 及び (b) はそれぞれ $P R=100$ における NO-LIF による側壁付きのノズル周りの流れ場及 び側壁のないノズル周りの流れ場を $x z$-平面で可視化した画 像である. Fig.9(a) から, 側壁付きノズルの噴流境界はノズ ル中心軸に対してほぼ平行となることが確認できる. 一方, Fig.9(b) から, 側壁のないノズルの噴流境界は下流に向かう につれてノズル中心軸方向へ収束する様子が確認できる。し かしながら，側壁付きノズル及び側壁のないノズル周りの流 れ場は，共に，スパイクを隔てた両噴射口から流出する噴流 がスパイク後端で膨張し、ベース面直後のノズル中心軸上で 干渉する様子が確認できる。この干渉領域は高圧力となり, 干渉領域より低圧力であるベース面に向かって逆流が生じ, この逆流がベース面に衝突することでベース面の圧力を上昇 させる ${ }^{3)}$. しかし, 逆流の構造自体は NO-LIFによって可視 化できなかった.

次に, ベース面の圧力上昇がスパイク切断による推力損 失を補填することを実験的に調查するために PSP を適用し てベース面の圧力分布計測を行った. Fig.10は PSP により 計測したベース面の平均圧力を示したものである. 縦軸に示 すべース面の平均圧力は膨張室圧力 $\left(P_{a}\right)$ で無次元化した. Fig.10に示すように, 側壁のないノズルの平均圧力はどの 圧力比においても $P / P_{a} \approx 1$ である. つまり, 側壁のない) ズルではどの圧力比でもべース面の圧力は外気圧力と等しい ので，スパイク切断による推力損失を補填しない，一方，側 壁付きノズルは低圧力比ではベース面の圧力は外気圧とほぼ 等しいが，高圧力比になるにつれてべース面の圧力が高くな り, $P R=200$ では $P / P_{a} \approx 1.4$ である. 以上の結果から, 側壁のないノズルのノズルの場合, 圧力比に関わらずベース 面の圧力はほぼ外気圧に等しいのでスパイク切断による推力 損失が補填されないことを明らかにした。一方，側壁付きノ ズルの場合, 低圧力比ではベース面の圧力はほぼ外気圧と等 しく, スパイク切断による推力損失を補填しないが, 高圧力 比になるに従ってベース面の圧力は上昇してスパイク切断に よる推力損失を補填すると考えられる。

\section{4 結論}

本研究では, リニアエアロスパイクノズルに対して側壁の 有無による流れ場構造を解析するため, NO-LIFによる可視 化技術を用いて任意断面で可視化するとともに，PSP によ る圧力計測法を用いてリニアエアロスパイクノズル表面の圧

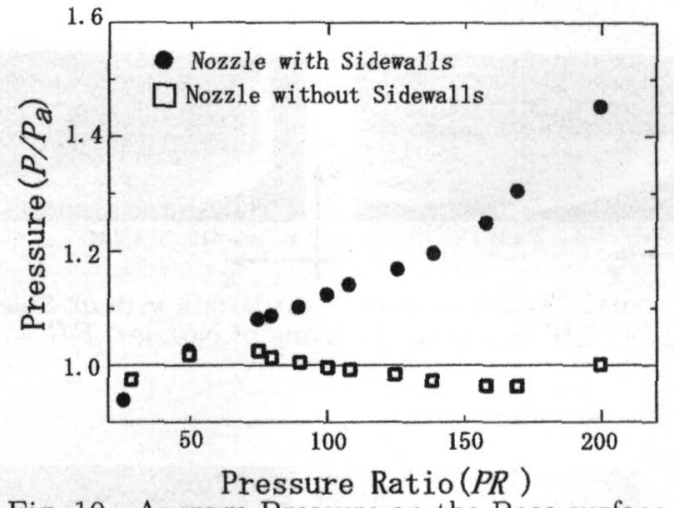

Fig. 10 Average Pressure on the Base surface

力分布計測を行った. 本研究で得られた結果を以下に示す.

1. スパイク長 $60 \%$ のズル（Nozzle A）の流れ場の解析 結果から，側壁設置によって噴流の側方への膨張は抑制 され，噴流は設計圧力比において適正膨張することを明 らかにした. また, 側壁設置によりスパイク表面の圧力 が高くなるので, 推力の增加が見込まれる.

2. 側壁を付けた Nozzle A の流れ場の解析結果から, エア ロスパイクノズルの特徵である圧力比の変化に伴う噴流 の変化を確認し, 設計圧力比以上でスパイク表面の圧力 は外気圧に依存せず, 一方で, 設計圧力比未満では, 噴 流圧力が外気圧と等しくなる場所で圧力が上昇すること を実験的に明らかにした。

3. スパイク長 $20 \%$ のノ゙ル（Nozzle B）の流れ場の解析 結果から，側壁のないノズルの場合, ベース面の平均圧 力は低圧力比から高圧力比までほぼ外気圧と等しいので, スパイク切断による推力損失を補填しない。,一方, 側壁 付きノズルの場合, 圧力比が高くなるにつれてベース面 の平均圧力は上昇し, スパイク切断による推力損失を補 填すると思われる。

\section{謝辞}

本研究は科学研究費補助金の援助により実施した. ここに 謝意を表する。なお，本研究で使用したノズルの製作には本 学技術室の中西幸弘氏にご尽力いただいた. 心より感謝申し 上げる.

\section{参考文献}

1) Rao. G.V.R., Ballistic Missile and Space Technology, Vol.2, Pergamon Press, (1961), pp.92-101.

2）新美智秀ほか，日本航空宇宙学会論文集，52 (2004), pp.235-240.

3) T. Ito, et al., Trans. Japan Soc. Aero. Space. Sci., $\mathbf{4 7}$ (2004), pp.17-22.

4) T. Ito, et al., AIAA Paper 2004-4018, (2004).

5) H. Mori, et al., Journal of Visualization, 7 (2004), pp.55-62.

6) Y. Amao, et al., Polymer Journal, 31 (1999), pp.12671269.

7) C. Lee and D. Thompson, NASA TM X-53019 (1964).

8) F. Nasuti, et al., Journal of Propulsion and Power, 15 (1999), pp.544-551. 